\title{
A Critical Study of Factors Influencing the Microbiological Assay of Nicotinic Acid
}

\author{
By E. KODICEK ANd CATHERINE R. PEPPER \\ Dunn Nutritional Laboratory, University of Cambridge \\ and Medical Research Council
}

SUMMARY: The cultural characters of a strain of Lactobacillus arabinosus and $L$. helveticus used in the microbiological assay of riboflavin and nicotinic acid proved to be typical, excepting that neither strain fermented xylose and the strain of $\boldsymbol{L}$. arabinosus fermented rhamnose but not raffinose. Neither produced catalase, so that a strongly positive catalase test in these cultures indicates probable contamination by common air-borne micro-organisms.

Modifications of the medium to achieve maximum acid production were investigated by altering, omitting or adding various constituents. A modified medium was adopted allowing a slightly higher acid production. In this medium the maximum acid production was obtained in the presence of natural substances like peptone. The maximal acid production obtainable with nicotinic acid alone was slightly lower, suggesting an additional specific factor in peptone. No confirmatory evidence, however, could be obtained of its existence. Linoleic acid in a concentration of $640 \mu \mathrm{g} . / 10 \mathrm{ml}$. medium depressed the acid production, and its action was antagonized by cholesterol. Other fatty acids and lipids had no effect.

A good reproducibility and a small coefficient of variation was found between tubes at various levels of nicotinic acid within any one assay, but between separate assays the variation was high (coefficient of variation $=12-19 \%$ ).

Since Snell \& Wright (1941) published their original microbiological procedure for the estimation of nicotinic acid, it has been modified by a number of workers (Krehl, Strong \& Elvehjem, 1943; Barton-Wright, 1944, 1945; Sarett, Pederson \& Cheldelin, 1945). Experience in the assay of riboflavin with Lactobacillus helveticus showed that, by the use of an improved medium, a higher acid production and an increased reproducibility could be obtained (Kodicek, 1948; Pepper, 1947). An attempt was made to improve conditions likewise for the nicotinic acid assay, with $L$. arabinosus as the test organism.

\section{EXPERIMENTAL}

Cultural characteristics of Lactobacillus arabinosus and Lactobacillus helveticus

The characteristics and biochemical reactions of $L$. arabinosus were compared with those of L. helveticus. Snell's original strain L. arabinosus, 17-5 (Snell \& Wright, 1941) was obtained from Dr Snell in 1944. After monthly subculture on yeast-water glucose agar slopes, and storage of the tubes at $4^{\circ}$, it was found in 1945 to be unsuitable for the assay of nicotinic acid. The bacteria had lost their sensitivity; their response to graded doses of nicotinic acid was very erratic, and the agreement between tubes at each level of addition was poor. A fresh culture kindly supplied by Dr Barton-Wright was investigated. It proved to be the $p$-aminobenzoic acid mutant described by Snell (see Shankman, 1943). Lewis also described this mutant strain (see Pennington, 1946) and 
stated that his stock culture, used as the test organism for this particular assay, suddenly acquired the ability to dispense with $p$-aminobenzoic acid.

The strain of $L$. helveticus, obtained from Dr Barton-Wright in 1943, was derived from Snell's original strain no. 7499 A.T.C. (Snell \& Strong, 1939). It was in continuous use for experimental work from the time it was obtained and never showed any sign of mutation; its response to added riboflavin was constant and satisfactory.

Both strains had the following features, characteristic of members of the genus Lactobacillus: Gram-positive, non-motile, non-sporing, micro-aerophilic, aciduric, fermenting carbohydrates to give lactic acid but no gas, pleomorphism and irregular beaded staining in old culture, growing well only on complex media, indole negative, methyl red positive, and catalase negative. When testing the organisms for their sugar reactions, yeast extract was added to the tubes. When this was not done, falsely negative results occurred, merely because of lack of growth.

Wilson \& Miles (1946) state that some of the Lactobacilleae are very slightly catalase-positive. With these two organisms there was no spontaneous evolution of gas upon adding $\mathrm{H}_{2} \mathrm{O}_{2}$, although in the course of several hours a few bubbles of $\mathrm{O}_{2}$ did collect. The initial lack of reaction provided a quick and useful check test for contamination of the cultures. Since the common airborne bacteria are strongly positive, and contamination from bacteria other than these is very unlikely, an immediate production of $\mathrm{O}_{2}$ is indicative of contamination.

L. helveticus ferments litmus milk rapidly, and after $48 \mathrm{hr}$. at $37^{\circ}$ there is an acid clot and reduction in the lower portion of the tube; $L$. arabinosus, on the other hand, takes its place in Type B of White \& Avery's classification (1910), producing insufficient acid to clot the milk (even after 5 days' incubation), although here again reduction occurs slowly in the lower part of the tube.

McIntosh, James \& Lazarus-Barlow (1922) and Day \& Gibbs (1928), working with lactobacilli associated with dental decay, reported that the reactions of individual strains were not constant. With $L$. arabinosus and L. helveticus, however, we obtained the same results (Table 1) on six occasions. Some of these fermentations were atypical according to Bergey (1939), but with one exception agreed with the findings of Camien, Dunn \& Salle (1947), who studied extensively the effect of various carbohydrates upon the acid production of different strains of lactobacilleae; in this laboratory $L$. arabinosus has always fermented rhamnose but not raffinose.

\section{Alterations of medium}

The effect of altering single constituents of the medium for nicotinic acid assay was studied, in order to obtain an improved medium which would contain growth substances in optimal concentrations (see Leonian \& Lilly, 1945); and allow for greater accuracy from a steeper response curve. Unless otherwise stated, Barton-Wright's procedure (1944) was used; the results reported are means of 3-6 tubes. 
Modification of Barton-Wright's basal medium. The following alterations of Barton-Wright's basal medium (1944) were made. The quantities quoted refer to concentrations in $100 \mathrm{ml}$. of final basal medium.

(i) The glucose concentration was increased from 2 to $3 \mathrm{~g} . / 100 \mathrm{ml}$.

(ii) Potassium acetate was used instead of sodium acetate and the concentration increased from 2 to $3 \mathrm{~g} . / 100 \mathrm{ml}$.

(iii) Phosphate solution $(20 \mathrm{~g} . / 100 \mathrm{ml}$.). The amount added was increased from 0.5 to $2 \mathrm{ml} . / 100 \mathrm{ml}$.

Table 1. Sugar fermentation tests

\begin{tabular}{|c|c|c|}
\hline Sugar & L. helveticus & L. arabinosus \\
\hline Arabinose & - & + \\
\hline Dextrin & - & - \\
\hline Glucose & + & + \\
\hline Dulcite & - & - \\
\hline Galactose & + & + \\
\hline Glycerol & - & - \\
\hline Inosite & - & - \\
\hline Inulin & - & - \\
\hline Lactose & + & + \\
\hline Fructose & + & + \\
\hline Maltose & - & + \\
\hline Mannitol & - & + \\
\hline Mannose & + & + \\
\hline Raffinose & - & - \\
\hline Rhamnose & + & + \\
\hline Salicin & + & + \\
\hline Sorbitol & - & + \\
\hline Sucrose & - & + \\
\hline Trehalose & + & + \\
\hline Xylose & - & - \\
\hline
\end{tabular}

(iv) A salt solution $(E)$ containing $\mathrm{Mg}, \mathrm{Mn}, \mathrm{Fe}, \mathrm{Cu}, \mathrm{Zn}$ sulphates and $\mathrm{NaCl}$ (Table 6) was used in place of salt solution $B$ (Snell \& Strong, 1939).

These four modifications previously found optimal for the riboflavin assay (Kodicek, 1948) were adopted as being those most likely to encourage a high acid production by $L$. arabinosus.

(v) Casein. Spray-dried acid-hydrolyzed casein powder for microbiological assay work (Ashe Laboratories Ltd.) was tested in concentrations from $\mathbf{0 . 3}$ to $3 \mathrm{~g} . / 100 \mathrm{ml}$. As will be seen from Table 2, the blanks gave too high an acid response when concentrations of, or higher than, $1 \mathrm{~g} . / 100 \mathrm{ml}$. were used. The same maximum acid production was obtained both with $0.3 \mathrm{~g}$. and with $0.5 \mathrm{~g}$. casein, and $0.3 \mathrm{~g} . / 100 \mathrm{ml}$. was adopted for this particular sample of casein hydrolysate.

(vi) B vitamins. The concentrations of aneurin chloride hydrochloride, pyridoxin hydrochloride, $p$-aminobenzoic acid and calcium $d$-pantothenate were increased ten times from $0.01 \mathrm{mg} . / 100 \mathrm{ml}$. to $0.1 \mathrm{mg} . / 100 \mathrm{ml}$. each. The increased concentration of the B vitamins, however, had no significant effect on the acid production of $L$. arabinosus.

(vii) Purines. Adenine sulphate, guanine hydrochloride and uracil were added at different concentrations (Table 3 ). The concentration around 
$3 \mathrm{mg} . / 100 \mathrm{ml}$. seemed to be about optimal and was adopted in the final medium.

(viii) Cystine. Increasing the concentration of L-cystine from $0.02 \mathrm{~g}$. to $0.04 \mathrm{~g} . / 100 \mathrm{ml}$. produced no beneficial effect and, moreover, some of the cystine came out of solution when adjusting the $\mathrm{pH}$ of the medium to $6 \cdot 8$. The original concentration was therefore used throughout.

Table 2. Effect of increasing the concentration of acid-hydrolyzed casein

\begin{tabular}{|c|c|c|c|c|c|c|}
\hline & & Nic & inic a & $(\mu \mathrm{g}$. & ml. $\mathbf{n}$ & ium) \\
\hline & Concentration & 0 & 0.05 & $0 \cdot 1$ & $\mathbf{0} \cdot \mathbf{3}$ & 0.5 \\
\hline Material & (g./100 ml. medium) & & $1 \mathrm{~N}-\mathrm{a}$ & pro & ed $(n$ & \\
\hline Acid-hydrolyzed casein & $\mathbf{0}$ & $\mathbf{0}$ & $\mathbf{1 \cdot 3}$ & $1 \cdot 7$ & $\mathbf{2 \cdot 8}$ & $\mathbf{3} \cdot \mathbf{0}$ \\
\hline powder for microbio- & $0 \cdot 3$ & $1 \cdot 6$ & $4 \cdot 8$ & $6 \cdot 0$ & $9 \cdot 5$ & $12 \cdot 6$ \\
\hline logical work & $0 \cdot 5$ & $1 \cdot 7$ & $3 \cdot 4$ & $5 \cdot 1$ & $9 \cdot 0$ & $11 \cdot 5$ \\
\hline & $1 \cdot 0$ & $\mathbf{3} \cdot \mathbf{4}$ & $5 \cdot 5$ & $6 \cdot 2$ & $10 \cdot 4$ & $13 \cdot 0$ \\
\hline & $\mathbf{2} \cdot 0$ & $5 \cdot 5$ & $7 \cdot 6$ & $8 \cdot 6$ & $12 \cdot 2$ & $14 \cdot 1$ \\
\hline & $\mathbf{3} \cdot \mathbf{0}$ & $7 \cdot 4$ & $8 \cdot 0$ & $9 \cdot 5$ & $11 \cdot 7$ & $12 \cdot 0$ \\
\hline
\end{tabular}

Table 3. Effect of increasing the concentration of purines

\begin{tabular}{|c|c|c|c|c|c|c|}
\hline & & Nic & iic a & ( $\mu \mathrm{g})$. & ml. $\mathrm{n}$ & ium) \\
\hline & Concentratio & $\mathbf{0}$ & $\mathbf{0} \cdot \mathbf{1}$ & $\mathbf{0 . 2}$ & $0 \cdot 5$ & $1 \cdot 0$ \\
\hline Material & (g. $/ 100 \mathrm{ml}$. medium) & & $1 \mathrm{~N}-$ & 1 pro & $\operatorname{ced}(n$ & \\
\hline Purine solution & 0.001 & $0 \cdot 7$ & $4 \cdot 0$ & $6 \cdot 2$ & $10 \cdot 3$ & $12 \cdot 1$ \\
\hline & 0.003 & $1 \cdot 1$ & $4 \cdot 2$ & $6 \cdot 5$ & $11 \cdot 6$ & $14 \cdot 2$ \\
\hline & 0.005 & $\mathbf{0}$ & $3 \cdot 4$ & $5 \cdot 8$ & $11 \cdot 8$ & 11.5 \\
\hline & 0.010 & $\mathbf{0}$ & $3 \cdot 6$ & $5 \cdot 0$ & $10 \cdot 5$ & $12 \cdot 6$ \\
\hline
\end{tabular}

Purine solution contained adenine sulphate, guanine hydrochloride and uracil, $1 \mathrm{mg} . / \mathrm{ml}$. each.

(ix) Buffers. Various buffer solutions (Guirard, Snell \& Williams, 1946) were tested instead of potassium acetate (Table 4). As they did not increase the acid production, $3 \mathrm{~g} . / 100 \mathrm{ml}$. of potassium acetate were retained.

Additions to the basal medium. The following sugars, which were fermented by $L$. arabinosus, were added in turn to the medium (already containing $3 \mathrm{~g}$. glucose) in a concentration of $1.5 \mathrm{~g} . / 100 \mathrm{ml}$. : L-arabinose, galactose, mannose, mannitol, inositol and lactose. None of these compounds gave a significant increase in acid production. Acid production decreased when sucrose, but not when fructose, was substituted for glucose. Glucose was retained in the final medium.

Various other substances, including some of those reported by other workers as growth stimulants, were tested in turn. Under existing conditions no improvement was found on adding them in the following amounts per $100 \mathrm{ml}$.

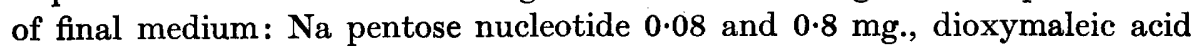
6.4 mg., maleic acid 6.4 mg., succinic acid 6.4 mg., choline chloride $100 \mathrm{mg}$, folic acid $2.5 \mathrm{mg}$., asparagine $2000 \mathrm{mg}$, glutamine $0.1 \mathrm{mg}$., glutamic acid 
(added before and after autoclaving tubes) $0 \cdot 1,0 \cdot 2$ and $10 \mathrm{mg}$. , methionine $1.2 \mathrm{mg}$. and thioglycollic acid 100 and $700 \mathrm{mg}$.

Table 4. Effect of alterations of buffer

\begin{tabular}{|c|c|c|c|}
\hline & & & um) \\
\hline & & o & $0 \cdot 5$ \\
\hline Buffer & (g./100 ml. medium) & $0.1 \mathrm{~N}$ & $(\mathrm{ml})$. \\
\hline $\mathbf{K}$ acetate (own medium) & $\mathbf{3}$ & $\mathbf{0}$ & $9 \cdot 7$ \\
\hline Na acetate & $0.01\}$ & 0.6 & $7 \cdot 0$ \\
\hline $\mathbf{K H}_{2}$ citrate & $0.25\}$ & 0.6 & 7.0 \\
\hline $\mathrm{K}$ acetate & $0.01\}$ & 0.5 & $7 \cdot 4$ \\
\hline $\mathbf{K H}_{2}$ citrate & $0.25\}$ & & \\
\hline $\mathrm{Na}$ acetate & $0.1\}$ & 1.5 & $\mathbf{9 \cdot 3}$ \\
\hline $\begin{array}{l}\mathbf{K H}_{\mathbf{2}} \text { citrate } \\
\mathrm{K} \text { acetate }\end{array}$ & $2 \cdot 2\}$ & & \\
\hline NaAc & $\left.\begin{array}{l}0.1 \\
2.2\end{array}\right\}$ & $1 \cdot 3$ & $\mathbf{9 \cdot 4}$ \\
\hline
\end{tabular}

Table 5. The effect of omitting individual constituents from the medium

\begin{tabular}{|c|c|c|}
\hline Constituents omitted & $\begin{array}{l}0.1 \mathrm{~N} \text { acid production (at } \\
0.5 \mu \mathrm{g} \text {. nicotinic acid } \\
\text { level } / 10 \mathrm{ml} . \text { medium) } \\
\text { (ml.) }\end{array}$ & $\begin{array}{l}\% \text { of acid production } \\
\text { in 'complete' medium }\end{array}$ \\
\hline 0 (control 'complete' medium) & $10 \cdot 0$ & - \\
\hline Glucose & $0 \cdot 4$ & 4 \\
\hline Xylose & $10 \cdot 1$ & 101 \\
\hline Potassium acetate & $5 \cdot 2$ & 52 \\
\hline Casein, acid-hydrolyzed & 0.7 & 7 \\
\hline Tryptophan & $\mathbf{3 \cdot 3}$ & $\mathbf{3 3}$ \\
\hline Cystine & $6 \cdot 7$ & 67 \\
\hline Adenine sulphate & 8.2 & 82 \\
\hline Guanine hydrochloride & $8 \cdot 3$ & 83 \\
\hline Uracil & $8 \cdot 1$ & 81 \\
\hline Xanthine & $10 \cdot 2$ & 102 \\
\hline Biotin (free acid) & $\mathbf{2 \cdot 0}$ & 20 \\
\hline Aneurin & $9 \cdot 1$ & 91 \\
\hline Riboflavin & $10 \cdot 1$ & 101 \\
\hline Pyridoxin hydrochloride & $8 \cdot 6$ & 86 \\
\hline Calcium $d$-pantothenate & $\mathbf{5 \cdot 3}$ & 53 \\
\hline$p$-Aminobenzoic acid & $9 \cdot 9$ & 99 \\
\hline Salt solution A (phosphate) & $5 \cdot 8$ & $\mathbf{5 8}$ \\
\hline Salt solution $\mathbf{E}$ & $7 \cdot 0$ & 70 \\
\hline Ammonium sulphate & $11 \cdot 2$ & 112 \\
\hline
\end{tabular}

Omissions from the basal medium. The substances listed in Table 5 were omitted in turn from basal medium to which $5 \mu \mathrm{g} . / 100 \mathrm{ml}$. of nicotinic acid had been added. The table gives the average results from three separate experiments. Since omission of xylose had no effect, and it was not fermented by $L$. arabinosus, it was not included in the final medium. Riboflavin was found to be non-essential, confirming the work of other authors (Snell \& Strong, 1938; Krehl et al. 1943; Snell, 1945; Barton-Wright, 1945) and was also omitted, as were ammonium sulphate and xanthine. The maintained acid production of our strain of $L$. arabinosus, in absence of $p$-aminobenzoic acid, showed that we 
have the $p$-aminobenzoic acid mutant mentioned by Snell (Shankman, 1943; Shankman, Camien, Block, Merrifield \& Dunn, 1947). The vitamin was, nevertheless, included in the final medium in case the mutant strain reverted to the normal type. Omission of the other constituents lowered the acid production, and they were retained in the final medium.

Table 6. Table of composition of own final medium and of other authors

\begin{tabular}{|c|c|c|c|c|c|}
\hline Constituents* & $\underset{\text { medium }}{\text { Owg.) }}$ & $\begin{array}{c}\text { Barton- } \\
\text { Wright (1945) } \\
\text { (mg.) }\end{array}$ & $\begin{array}{l}\text { Krehl et al. } \\
\text { (1943) } \\
\text { (mg.) }\end{array}$ & $\begin{array}{l}\text { Sarett et al. } \\
\quad \text { (1945) } \\
\text { (mg.) }\end{array}$ & $\begin{array}{l}\text { Woolley \& } \\
\text { Sebrell (1945) } \\
\text { (mg.) }\end{array}$ \\
\hline Glucose & 3000 & 2000 & 2000 & 2000 & 2500 \\
\hline Potassium acetate & 3000 & $2000(\mathrm{NaAc})$ & $2000(\mathrm{NaAc})$ & 1800 (NaAc) & $2000(\mathrm{NaAc})$ \\
\hline $\begin{array}{l}\text { Casein powder, acid-hydro- } \\
\text { lyzed vitamin-free }\end{array}$ & $\mathbf{3 0 0}$ & 600 & 500 & 500 & 1000 \\
\hline L-Tryptophan & 10 & $10(\mathrm{DL})$ & $10(\mathrm{DL})$ & - & $10(\mathrm{DL})$ \\
\hline L-Cystine & 20 & 20 & 20 & 20 & 10 \\
\hline Adenine sulphate & $\mathbf{3}$ & $\mathbf{1}$ & $\mathbf{1}$ & - & 1 \\
\hline Guanine hydrochloride & $\mathbf{3}$ & $\mathbf{1}$ & $\mathbf{1}$ & - & $\mathbf{1}$ \\
\hline Uracil & $\mathbf{3}$ & 1 & 1 & - & $\mathbf{1}$ \\
\hline Xanthine & - & $\mathbf{1}$ & - & - & - \\
\hline $\mathrm{KH}_{2} \mathrm{PO}_{4}$ & 200 & 50 & 50 & 50 & 50 \\
\hline $\mathrm{K}_{2} \mathrm{HPO}_{4}$ & 200 & 50 & 50 & 50 & 50 \\
\hline $\mathrm{MgSO}_{4} \cdot 7 \mathrm{H}_{2} \mathrm{O}$ & 120 & 20 & 20 & 20 & 20 \\
\hline $\mathrm{MnSO}_{4} .4 \mathrm{H}_{2} \mathrm{O}$ & $\mathbf{3}$ & 1 & $\mathbf{1}$ & 1 & 1 \\
\hline $\mathrm{NaCl}$ & 1 & 500 & 1 & $\mathbf{1}$ & $\mathbf{1}$ \\
\hline Xylose & - & 100 & - & - & - \\
\hline Ammonium sulphate & - & 300 & - & - & - \\
\hline \multicolumn{6}{|l|}{ Lloyd's reagent treated: } \\
\hline Peptone & - & - & - & 250 & - \\
\hline Liver extract & - & - & - & 100 & - \\
\hline Yeast extract & - & - & - & 100 & - \\
\hline \multirow[t]{2}{*}{ Norite treated yeast extract } & - & - & - & 100 & - \\
\hline & ( $\mu \mathrm{g})$. & ( $\mu$ g.) & $(\mu \mathrm{g})$. & ( $\mu \mathrm{g})$. & ( $\mu$ g.) \\
\hline $\mathrm{FeSO}_{4} \cdot 7 \mathrm{H}_{2} \mathrm{O}$ & 8 & 1000 & 1000 & 1000 & 1000 \\
\hline $\mathrm{CuSO}_{4} .5 \mathrm{H}_{3} \mathrm{O}$ & 8 & - & - & - & 一 \\
\hline $\mathrm{ZnSO}_{4} .7 \mathrm{H}_{2} \mathrm{O}$ & 8 & - & - & - & 一 \\
\hline Biotin (free acid) & 0.04 & 0.04 & 0.02 & - & $0 \cdot 1$ \\
\hline $\begin{array}{l}\text { Aneurin chloride hydro- } \\
\text { chloride }\end{array}$ & 100 & 10 & 10 & - & 20 \\
\hline Pyridoxin hydrochloride & 100 & 12 & 10 & - & 20 \\
\hline Calcium $d$-pantothenate & 100 & 10 & 10 & 10 & 40 \\
\hline$p$-Aminobenzoic acid & 100 & 10 & 10 & - & 20 \\
\hline Riboflavin & - & 20 & 20 & - & 40 \\
\hline
\end{tabular}

* Amounts stated per $100 \mathrm{ml}$. final medium (50 ml. of double-strength medium finally diluted to $100 \mathrm{ml}$.).

\section{Results with the alterations in the medium}

Table 6 shows the composition of our medium as finally modified and of the different basal media reported by other workers.

Our best response curve (Fig. 1) showed a greater acid production than that cited by Barton-Wright (1945), but taking the average response at different levels for 71 standard reference curves obtained in the course of over one year, the values for the improved medium were only slightly higher. The variation from experiment to experiment was considerable; for 71 experiments the 
coefficient of variation calculated for different levels of nicotinic acid ranged from 12 to $19 \%$ (Table 7). On the other hand, in one single experiment the agreement between tubes at various levels of nicotinic acid was found to be very close and the variation small (Table 8).

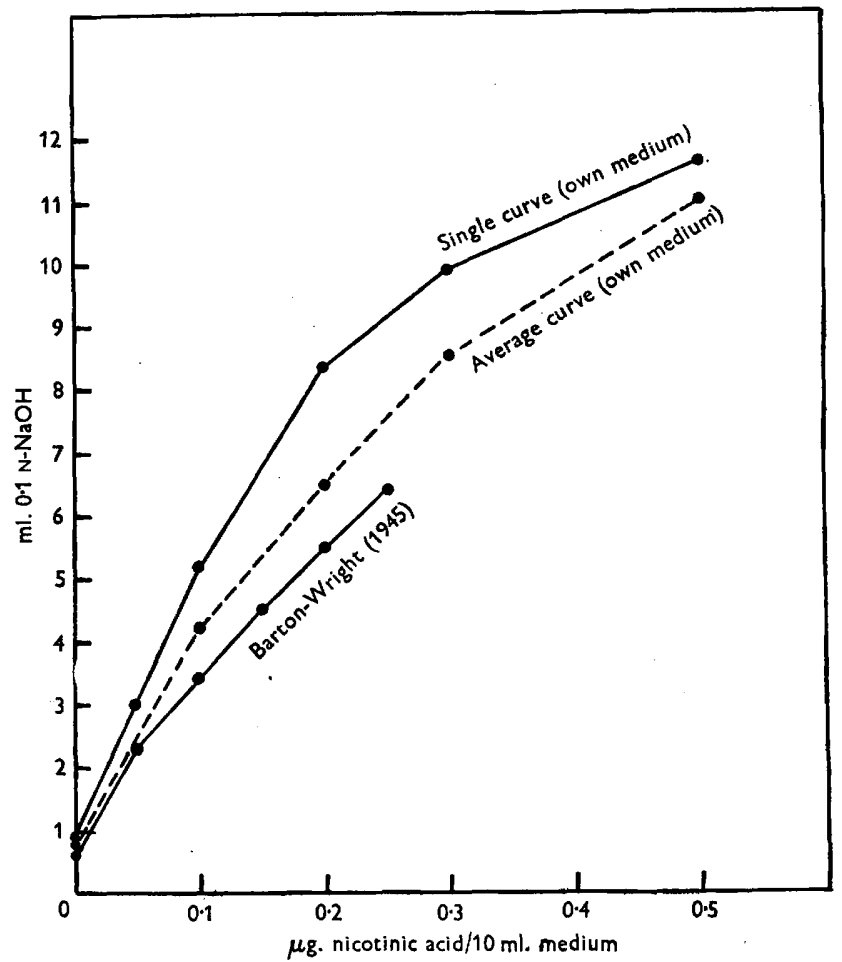

Fig. 1. Dose response curve of $L$. arabinosus in different media.

It was difficult to compare our average values for the standard reference curve with figures reported by other workers, as they do not indicate whether their curves referred to average values nor do they give any idea of their variation.

Because of the great variation in the acid productions from one experiment to another, the effect of altering the various constituents of the medium were tested within one experiment, and a control standard curve was always determined at the same time.

A similar erratic response was found when using $L$. helveticus with a certain riboflavin-free medium. When this was modified to give an acid production several times greater than the original, the results were then far more reproducible (coefficient of variation 3-7\%; Kodicek, 1948). Some deficiency of the medium may also be the reason for the erratic responses with $L$. arabinosus. As will be seen below, this organism is also capable of producing large amounts of acid of the order of that produced by $L$. helveticus. 


\section{Acid-producing potentialities of Lactobacillus arabinosus}

In order to determine whether $L$. arabinosus was capable of such high acid production as $L$. helveticus in the riboflavin assay, $L$. arabinosus was seeded into a modified riboflavin-free medium containing $0.5 \mu \mathrm{g} . / 10 \mathrm{ml}$. of added nicotinic acid. The acid production was between 22 and $27 \mathrm{ml}$. equivalents of

\section{Table 7. Average acid production in modified medium} and variation between experiments

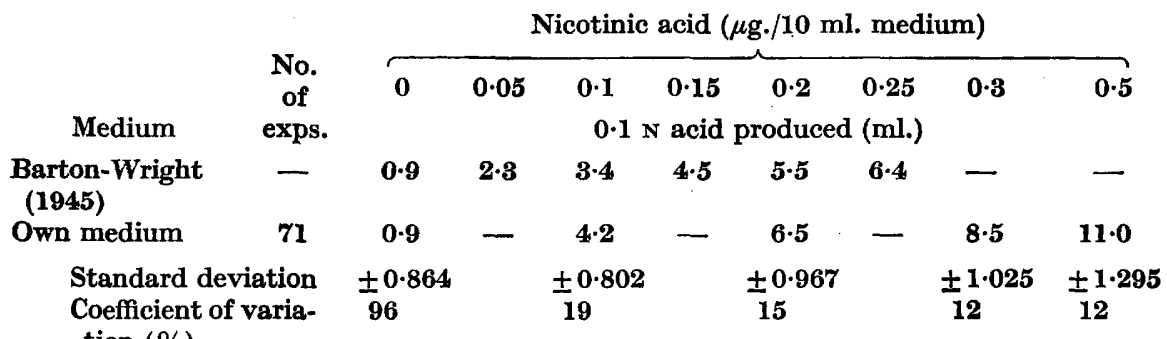

Table 8. Variation between tubes

\begin{tabular}{|c|c|c|c|c|}
\hline $\begin{array}{l}\text { Concentration of } \\
\text { nicotinic acid } \\
(10 \mathrm{ml} . \text { medium })\end{array}$ & $\begin{array}{l}\text { No. of } \\
\text { tubes }\end{array}$ & $\begin{array}{l}0 \cdot 1 \mathrm{~N} \text { acid } \\
\text { produced } \\
\quad(\mathrm{ml} .)\end{array}$ & $\begin{array}{l}\text { Standard } \\
\text { deviation }\end{array}$ & $\begin{array}{c}\text { Coefficient of } \\
\text { variation } \\
(\%)\end{array}$ \\
\hline $0 \cdot 1 \mu \mathrm{g}$ & 22 & $4 \cdot 3$ & \pm 0.258 & $6 \cdot 0$ \\
\hline $0.2 \mu \mathrm{g}$ & 22 & $7 \cdot 1$ & \pm 0.213 & $3 \cdot 0$ \\
\hline
\end{tabular}

$0.1 \mathrm{~N}-\mathrm{NaOH}$. When, however, peptone was omitted from the medium it no longer supported such high acid production. When photolyzed Bacto-peptone (Snell \& Strong, 1939) was added in a comparable concentration, i.e. $100 \mathrm{mg} . /$ $10 \mathrm{ml}$., to the modified medium used in the nicotinic acid assay, the acid production at $0.5 \mu \mathrm{g}$. nicotinic acid/10 ml. was increased from about 11 to 22 ml. equivalents. Untreated Bacto-peptone had a similar effect; in 13 experiments the average acid production was $21.3 \mathrm{ml} . \pm 0.698$ equivalents. Similar high values, however, were also obtained when no nicotinic acid was added (Table 9).

The nicotinic acid content of Bacto-peptone was found by chemical tests to be $37 \mu \mathrm{g}$. $/ \mathrm{g}$. The addition of $100 \mathrm{mg}$. of peptone $/ 10 \mathrm{ml}$. would add $3 \cdot 7 \mu \mathrm{g}$. of nicotinic acid to the nicotinic acid-free basal medium. To decide whether the high acid production could be attributed solely to nicotinic acid, the vitamin was added in comparable amounts to the basal medium (Table 9). Addition of peptone resulted in a slightly higher acid production than that found upon addition of $5 \mu \mathrm{g}$. of nicotinic acid. When the ' $t$ ' test was applied to test for the significance of the differences, the probability that these results were due to chance could not be excluded.

Further experiments were carried out to distinguish the peptone factor from nicotinic acid. The factor which seems to increase the acid production above 
that obtained with a corresponding level of nicotinic acid was stable to alkali, insensitive to light, not precipitated by $90 \%$ ethanol, not extractable by $\mathrm{CHCl}_{3}$ at acid $\mathrm{pH}$, adsorbed completely on activated charcoal at acid $\mathrm{pH}$, and partially at neutral $\mathrm{pH}$. These properties are similar to those of nicotinic acid and no conclusion could be drawn from these experiments. Further work on this matter is being carried out.

It is clear that $L$. arabinosus is capable of producing as much acid as L. helveticus (Fig. 2). The shape of the response curve is such that the increased acid production does not affect the lower portion of the response curve (between $0 \cdot 1$ and $0 \cdot 2 \mu \mathrm{g}$. of nicotinic acid) which is used for assay work.

Table 9. Comparison between acid productions in response to peptone and high amounts of nicotinic acid

\begin{tabular}{|c|c|c|c|c|}
\hline $\begin{array}{l}\text { Addition per } \\
10 \mathrm{ml} . \text { medium }\end{array}$ & $\begin{array}{c}\text { No. } \\
\text { of } \\
\text { exps. }\end{array}$ & $\begin{array}{c}\text { Average } \\
0 \cdot 1 \mathrm{~N} \text { acid } \\
\text { production } \\
\text { (ml.) }\end{array}$ & $\begin{array}{l}\text { Standard error } \\
\text { of the mean }\end{array}$ & Remarks \\
\hline \multicolumn{5}{|l|}{ Nicotinic acid: } \\
\hline $0.5 \mu \mathrm{g}$ & 71 & $11 \cdot 0$ & \pm 0.154 & - \\
\hline $5 \mu \mathrm{g}$. & 14 & $18 \cdot 6$ & \pm 0.473 & 一 \\
\hline $10 \mu \mathrm{g}$ & $\mathbf{5}$ & $19 \cdot 4$ & - & 一 \\
\hline $200 \mu \mathrm{g}$ & 1 & $18 \cdot 6$ & 一 & - \\
\hline \multicolumn{5}{|l|}{ Bacto-peptone: } \\
\hline $100 \mathrm{mg}$. & 9 & $20 \cdot 1$ & \pm 0.828 & $\begin{array}{l}\text { Equivalent to } \\
\mathbf{3} \cdot 7 \mu \mathrm{g} \text {. nic. acid }\end{array}$ \\
\hline $100 \mathrm{mg} .+0.5 \mu$ g. nic. acid & 13 & $21 \cdot 3$ & \pm 0.698 & $\begin{array}{l}\text { Equivalent to } \\
4 \cdot 2 \mu \text { g. nic. acid }\end{array}$ \\
\hline $100 \mathrm{mg} .+5 \mu \mathrm{g}$. nic. acid & 2 & $27 \cdot 8$ & - & - \\
\hline $100 \mathrm{mg} .+10 \mu \mathrm{g}$. nic. acid & 1 & $23 \cdot 5$ & - & 一 \\
\hline
\end{tabular}

\section{Inhibitory substances}

Iron and calcium. In view of the findings of Chattaway, Happold \& Sandford (1943), regarding the toxicity of certain cations, the effect of both iron and calcium was investigated in the modified final medium (Table 10) containing 0.1 and $0.5 \mu \mathrm{g}$. nicotinic acid $/ 10 \mathrm{ml}$. respectively.

$\mathrm{FeSO}_{4} \cdot 7 \mathrm{H}_{2} \mathrm{O}$ was added to a final maximum concentration of $1 \mathrm{mg} . / 100 \mathrm{ml}$. of medium. Calcium was added as $\mathrm{CaCl}_{2}$ in concentrations of 10,70 and $140 \mathrm{mg} . / 100 \mathrm{ml}$. These amounts were chosen as being considerably in excess of concentrations likely to occur in extracts from most iron- and calcium-rich foods.

As will be seen from Table 10, there was no significant decrease in acid production in the presence of the iron salts or of $\mathrm{CaCl}_{2}$. With extremely high concentrations of $\mathrm{CaCl}_{2}$ (70 and $140 \mathrm{mg}$. $/ 100 \mathrm{ml}$.) there was a certain decrease in acid production only at the level of $0.5 \mu \mathrm{g}$. nicotinic acid.

Linoleic acid and other fatty substances. Unlike $L$. helveticus, $L$. arabinosus has 
been reported to be insensitive to fatty acids ( $\mathrm{Krehl}$ et al. 1943). Their effect was tested on the organism used in this laboratory. Similar precautions were taken as in experiments with $L$. helveticus (Kodicek \& Worden, 1945), and the tests were repeated with $\mathrm{CHCl}_{3}$-extracted medium to prevent any interference

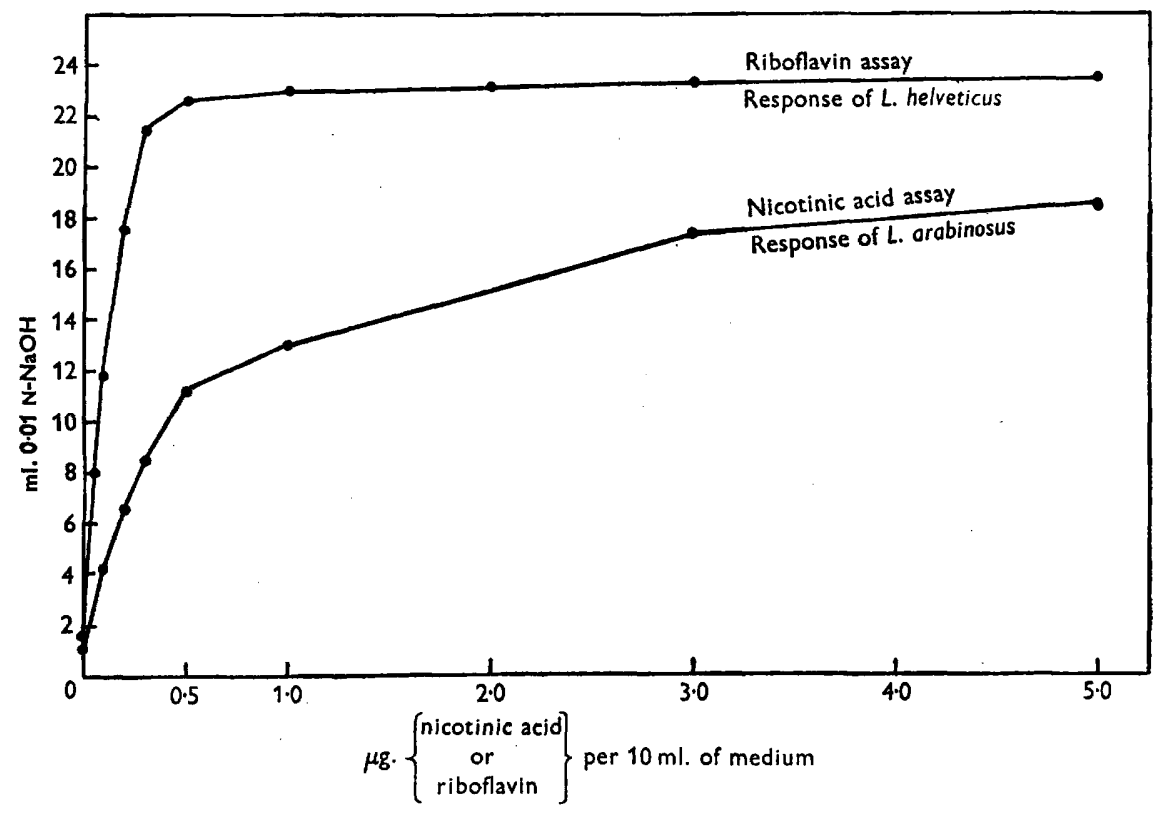

Fig. 2. Maximum acid production of $L$. arabinosus and $L$. helveticus on addition of essential vitamin.

Table 10. Effect of increasing the concentration of iron and calcium salts

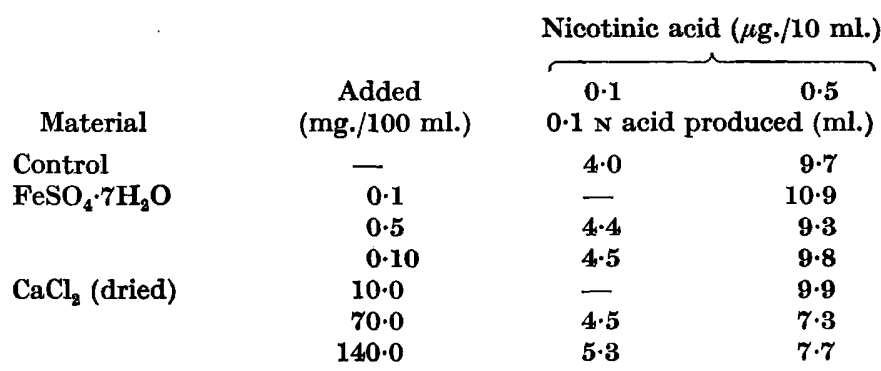

from fat-soluble substances. The results are shown in Table 11. The acid production in $\mathrm{CHCl}_{3}$-extracted medium was practically the same as that in the ordinary medium. There was almost complete inhibition of growth upon addition of $640 \mu \mathrm{g} . / 10 \mathrm{ml}$. of potassium linoleate (prepared from pure methyl linoleate, iodine value 173$)$. In presence of cholesterol $(640 \mu \mathrm{g} . / 10 \mathrm{ml}$.) this inhibition with linoleate did not take place. The inhibition by linoleic acid occurred, irrespective of whether $\mathrm{CHCl}_{3}$-extracted or ordinary medium was used. 
At a level of $160 \mu \mathrm{g}$. linoleic acid there was proportionally less inhibition. The depressant effect was more marked at higher levels of nicotinic acid (Fig. 3).

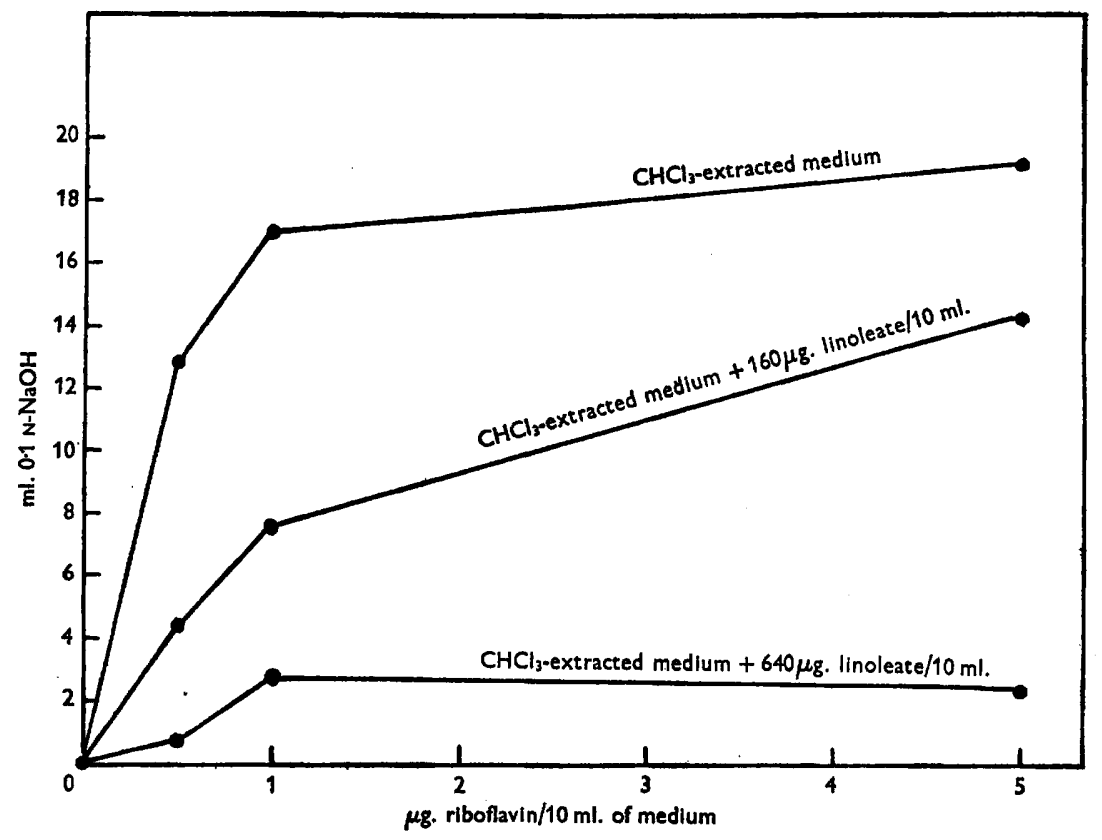

Fig. 3. Effect of linoleate on acid production of $L$. arabinosus.

Table 11. Effect of fatty acids and lipoids

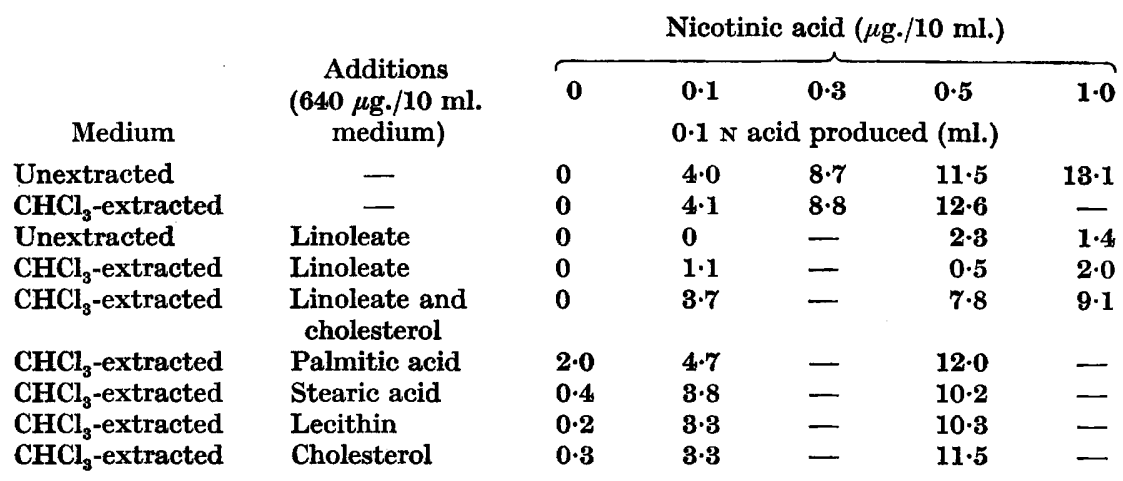

Palmitic and stearic acid, lecithin and cholesterol were each tested at a level of $640 \mu \mathrm{g} . / 10 \mathrm{ml}$. (Table 11); none of these substances had a marked effect on the acid production.

Kodicek \& Worden $(1945,1946)$ suggested that the inhibitory effect of linoleic acid might be due to the formation of a molecular monolayer on the surface of the bacteria. Accordingly, it was decided to investigate the effect 
of surface-active Aerosols. These compounds are long chain di-esters of sodium sulpho-succinate, e.g.

$$
\begin{aligned}
& \mathrm{C}_{n} \mathrm{H}_{2 n+1} \mathrm{COO} . \mathrm{CH}_{2} \\
& \mathrm{C}_{n} \mathrm{H}_{2 n+1} \mathrm{COO} . \mathrm{CH} . \mathrm{SO}_{3} \ldots \mathrm{Na}^{+} .
\end{aligned}
$$

Two samples, Aerosol AY $(n=8)$ and IB $(n=5)$, were kindly supplied by the Colloid Science Department, Cambridge. As will be seen from Table 12, the Aerosols in concentrations of $640 \mu \mathrm{g} . / 10 \mathrm{ml}$. showed no such inhibitory effect as was observed with linoleic acid. It seems that the effect of linoleic acid, if it is a physico-chemical one, is different from that of detergents like Aerosols.

Table 12. Effect of linoleic acid and Aerosols added to $\mathrm{CHCl}_{3}$-extracted medium

Addition
$(640 \mu \mathrm{g} . / 10 \mathrm{ml}$. medium $)$
None
Linoleic acid
Aerosol 1 B
Aerosol AY

$\begin{array}{lc}\text { Nicotinic acid }(\mu \mathrm{g} . / 10 \mathrm{ml} .) \\ 0.1 \mathrm{~N} \text { acid produced } \\ 0.5 & 0.5 \\ 0 & 11.5 \\ 0 & 0 \\ 1.7 & 12.3 \\ & 11.5\end{array}$

\section{DISCUSSION}

The strain of $L$. arabinosus used in this laboratory proved to be the $p$-aminobenzoic acid mutant mentioned by American workers. Its cultural characteristics agreed well with published findings with the exception of its fermenting properties for raffinose and rhamnose. The former, contrary to findings of Camien et al. (1947), was fermented by the organism, while raffinose was not.

We can confirm the growth-promoting effect of peptone (Pollack \& Lindner, 1943; Sarett et al. 1945; Camien et al. 1947), but we were unable to decide whether it was due to a specific factor or to the high nicotinic acid content of this substance.

We have omitted several constituents which were found to be non-essential for L. arabinosus, namely xylose, xanthine, ammonium sulphate and riboflavin, and, on the other hand, increased the concentration of glucose, potassium acetate, phosphates, magnesium, manganese salts and B-vitamins. Knight (1945) reported in his review that purines had definite growth-promoting effects on L. arabinosus. Sarett et al. (1945), however, found high amounts to be deleterious. We did not find this to be the case and increased the concentration of adenine, guanine and uracil. The amount of tryptophan was not altered, since no beneficial effect was found when increasing its concentration ten times above that used in the original medium.

Contrary to reports that iron salts exerted a marked depressing effect on certain bacteria, they did not interfere in our tests in concentrations which were in excess of those usually encountered when assaying iron-rich extracts. Calcium salts, only in a very high concentration, 70-140 mg./100 ml., decreased the acid production slightly, but such a high concentration of calcium is unlikely to occur in extracts of foodstuffs. 
Linoleic acid inhibited the acid production of $L$. arabinosus. Higher concentrations were needed than those that were bacteriostatic for $L$. helveticus. This relative insensitivity may explain the negative findings of previous workers. The inhibition could be counteracted by cholesterol, as was the case with $L$. helveticus. The mode of action, if it is a physico-chemical one, would be different from that of such detergents as Aerosols which are ineffective in comparable concentrations. We can confirm that stearic and palmitic acids, cholesterol and lecithin have no enhancing effect on the acid production even at high concentrations. For assay work, the removal of lipids is advisable because of possible effects by unsaturated fatty acids, although the relative insensitivity of $L$. arabinosus makes this less essential than when working with L. helveticus.

The modified final medium fell short of our expectations of obtaining the high acid production experienced in assays with $L$. helveticus. Within any one experiment the results between tubes agreed closely, but a rather high variation between experiments was observed. This somewhat erratic response from one experiment to another will be referred to in another paper (Kodicek \& Pepper, 1948) which deals with actual results on foodstuffs. There the reproducibility of the nicotinic acid values in repeats and the good agreement between chemical and microbiological values contrast pleasantly with our experience of the response of $L$. arabinosus towards nicotinic acid alone. Nevertheless, we feel that $L$. arabinosus is not the most appropriate organism for nicotinic acid assays. Its effective range for assay of nicotinic acid is far below its optimal requirements for this vitamin; under certain conditions it may, on the other hand, dispense with nicotinic acid (Shankman et al. 1947).

We wish to thank Drs A. E. Alexander and A. I. McMullen for kindly supplying us with samples of Aerosols. Our thanks are due to Dr L. J. Harris for his continued interest in this work and Dr C. G. McGaughey for the facilities kindly granted by the Institute of Animal Pathology, Cambridge.

\section{REFERENCES}

Barton-Wright, E. C. (1944). The microbiological assay of nicotinic acid in cereals and other products. Biochem. $J .38,314$.

Barton-Wright, E. C. (1945). The theory and practice of the microbiological assay of the vitamin-B complex; together with the assay of selected aminoacids and potassium. Analyst, 70, 283.

Bergey's (1939) Manual of Determinative Bacteriology. Baltimore, 5 th ed.

Camien, M. N., Dunn, M. S. \& Salle, A. J. (1947). The effect of carbohydrates on acid production by twenty-four lactic acid bacteria. $J$. biol. Chem. 168, 33.

Chattaway, F. W., Happold, F. C. \& Sandford, M. (1943). The microbiological assay of riboflavin. The influence of inorganic constituents and unknown growth factors. Biochem. J. 37, 298.

DAY, A. A. \& GrBBs, W. M. (1928). Surface tension in relation to bacterial growth with special reference to Lactobacillus acidophilus and Lactobacillus bulgaricus. J. infect. Dis. 43, 97.

Guirard, B. M., SNEll, E. E. \& Wrlliams, R. J. (1946). The nutritional role of acetate for lactic acid bacteria. I. The response to substances related to acetate. Arch. Biochem. 9, 361. 
Isbell, H. (1945). The use of charcoal-treated peptone in microbiological assays. Science, $102,671$.

KnIGHT, B. C. J. G. (1945). Growth factors in microbiology. Some wider aspects of nutritional studies with micro-organisms. Vitamins and Hormones, 3, 105. N.Y. : Academic Press, Inc.

Kodicek, E. (1948). The microbiological assay of riboflavin. (In the Press.)

Kodrcek, E. \& PePper, C. R. (1948). The microbiological estimation of nicotinic acid and comparison with a chemical method. J. gen. microbiol. $2,306$.

Kodicek, E. \& Worden, A. N. (1945). The effect of unsaturated fatty acids on Lactobacillus helveticus and other Gram-positive micro-organisms. Biochem. J. 39, 78.

Kodicek, E. \& Worden, A. N. (1946). Effect of unsaturated fatty acids on the acid production of Lactobacillus helveticus. Nature, Lond., 157, 587.

Krehl, W. A., Strong, F. M. \& ElvehJem, C. A. (1943). Determination of nicotinic acid. Modification in the microbiological method. Industr. Engng Chem. (Anal. ed.), 15, 471.

Leonian, L. H. \& Lilly, V. G. (1945). The comparative value of different test organisms in the microbiological assay of $\mathbf{B}$ vitamins. Bull. W. Va agric. Exp. Sta. no. 319, 35.

McIntosh, J., James, W. W. \& Barlow, P. L. (1922). An investigation into the etiology of dental caries. I. The nature of the destructive agent and the production of artificial caries. Brit. J. exp. Path. 3, 138.

Pennington, D. (1946). Assay of $p$-aminobenzoic acid. Science, 103, 397.

Pepper, C. R. (1947). Microbiological studies on certain B-vitamins. M.Sc. Thesis, University of Cambridge.

Pollack, M. A. \& Lindner, M. (1943). A growth stimulant for Lactobacillus casei. J. biol. Chem. 147, 183.

Sarett, H. P., Pederson, R. L. \& Cheldelin, V. H. (1945). Microbiological assay methods for nicotinic acid. Arch. Biochem. 7, 7 7.

Shankman, S. (1943). Amino-acid nutrition of Lactobacillus arabinosus. J. biol. Chem. $150,305$.

Shankman, S., Camien, M. N., Block, H., Merrifield, R. B. \& DunN, M. S. (1947). Vitamin requirements of twenty-three lactic acid bacteria. J. biol. Chem. 168, 23.

SNELL, E. E. (1945). The nutritional requirements of the lactic acid bacteria and their application to biochemical research. $J$. Bact. 50, 373 .

Snell, E. E. \& Strong, F. M. (1938). The influence of riboflavin and certain synthetic flavins on the growth of lactic acid bacteria. J. biol. Chem. 123, cxii.

SNeli, E. E. \& Strong, F. M. (1939). A microbiological assay for riboflavin. Industr. Engng Chem. (Anal. ed.), 11, 346.

SNeli, E. E. \& Wright, L. D. (1941). A microbiological method for the determination of nicotinic acid. J. biol. Chem. 139, 675.

WhIte, B. \& AVERY, O. T. (1910). Observations of certain lactic acid bacteria of the so-called Bulgaricus type. Zbl. Bakt. (2. Abt.), 25, 161.

Wilson, G. S. \& Mrles, A. A. (1946). Topley and Wilson's Principles of Bacteriology and Immunity, p. 752. London: Edward Arnold and Co.

Woolley, J. G. \& Sebrell, W. H. (1945). Two microbiological methods for the determination of $l(-)$-tryptophane in proteins and other complex substances. J. biol. Chem. 157, 141. 